\title{
Of President Barack H. Obama and Others
}

Public Policy, Race-talk, and Pragmatism

Bill E. Lawson

\section{(2) OpenEdition}

Electronic version

URL: https://journals.openedition.org/ejpap/825

DOI: 10.4000/ejpap.825

ISSN: 2036-4091

Publisher

Associazione Pragma

\section{Electronic reference}

Bill E. Lawson, "Of President Barack H. Obama and Others", European Journal of Pragmatism and American Philosophy [Online], III-2 | 2011, Online since 29 December 2011, connection on 21

September 2021. URL: http://journals.openedition.org/ejpap/825 ; DOI: https://doi.org/10.4000/ejpap. 825

This text was automatically generated on 21 September 2021.

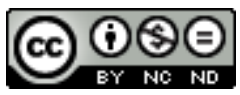

Author retains copyright and grants the European Journal of Pragmatism and American Philosophy right of first publication with the work simultaneously licensed under a Creative Commons AttributionNonCommercial-NoDerivatives 4.0 International License. 


\title{
Of President Barack H. Obama and Others
}

Public Policy, Race-talk, and Pragmatism

\author{
Bill E. Lawson
}

\section{AUTHOR'S NOTE}

I want to acknowledge the support of the Department of Philosophy at the University of Liverpool, particularly Gillian Howie, Simone Hailwood, and Stephen McLeod. A very special thanks to Dr. Fionnghuala Sweeney, Dionne Palmer, and Dr. Renée SandersLawson.

\section{"Souls" Revisited}

1 In 1903, W.E. B. Dubois published his seminal work, The Souls of Black Folk, which contained his scathing critique of Booker T. Washington entitled "Of Mr. Booker T. Washington and Others." In this critique, Dubois took issue with what he took to be the program of racial reconciliation that Washington proposed. Dubois claimed that Washington's program for the betterment of race relations in the United States was having a detrimental effect on the educational progress and social standing of black people. He claimed that the effects of Washington's program had negative consequences, in that it asked that black people give up, at least for the present, three things:

2 First, political power, Second, insistence on civil rights, Third, higher education of Negro youth, - and concentrate all their energies on industrial education, the accumulation of wealth, and the conciliation of the South. This policy has been courageously and insistently advocated for over fifteen years, and has been triumphant for perhaps ten years. As a result of this tender of the palm-branch, what has been the return? In these years there have occurred:

- The disfranchisement of the Negro. 
- The legal creation of a distinct status of civil inferiority for the Negro.

- The steady withdrawal of aid from institutions for the higher training of the Negro. ${ }^{2}$

3 According to Dubois, Blacks must forthrightly push and demand the status of full citizenship, equal educational opportunities, and full participation in the political process. To do less, according to Dubois, was to deny the very humanity of blacks. I disagree that Washington's program had the negative impact that Dubois accused it of having on the lives of black people, but that is the topic of another paper. ${ }^{3}$ While there is debate about the veracity of Dubois's critique, ${ }^{4}$ it made a lasting impression on millions of readers of Souls. His critique reminds us to be vigilant in our assessment of programs purportedly meant to help the black community and all Americans. election of President Obama, there have been many changes in the manner in which race and racism impact on the lives of African Americans, so much so that there are persons who now claim that the United States is in a "post-racial" state. The claim is that race and racism are no longer significant factors in the success of any person who wants to succeed. The claim is not that there is no longer individual acts of racism, but that societal racism has diminished to the point where race no longer matters. In the United States, at least, character has finally overcome color. ${ }^{5}$ The election of a non-white male as President of the United States attests to this important social fact. It is thought by some that the election of Obama shows how far the country has come in thinking about race relations. However, all of the economic indicators show that African Americans are still doing much worse, educationally, financially, and in terms of life expectancy, than whites, despite their extensive sojourn in the United States. President Obama realizes this important fact about black life in America. He has consistently proclaimed that his public policies will help the economic and social standing of blacks. Will his public policies really be effective in advancing the economic and social standing of black Americans?

One hundred and twenty-five years after the publication of Souls, I want to use a similar Duboisian critique of President Obama's programs of social and economic progress that, by his account, are meant to advance the social and political position of all Americans. The claim here is that his universalist approach to policy-making and implementation will have a detrimental impact on the social and economic standing of African Americans. It is his use of color-blindness as a guiding principle to direct public policies that is called into question. Will this approach address the social ills that have continually plagued the African American community? I think not. I also think that a pragmatic understanding of race-talk can help us understand why colorblind policies will not work to address the social and economic problems facing the black community. It is argued, herein, that color or race conscious policies are needed to address the social and economic problems that besiege the black community. This article will utilize a pragmatic account of race to illustrate why colorblindness in public policies takes an ahistorical and decontextualized view of race and in the long term will hurt the social and economic standing of African Americans, indeed all Americans.

In a manner similar to that of Dubois, I want to examine the logic of President Obama's position on colorblindness in public policies for the advancement of African Americans. At the outset, I want to claim that there are some interesting similarities between the lives of Obama and Washington. Obama came to the attention of the nation in the same manner as Washington: Washington's fame and prominence came after his 1895 Atlanta Exposition Address, ${ }^{6}$ and Obama's national fame came after his keynote address at the 
2004 Democratic National Convention. ${ }^{7}$ These speeches thrust both men into the public limelight and within a few years Washington was seen as the leader of black America and Obama was President of the United States. Let me be clear here, I am not equating any of Obama's political positions with those of Washington. These men come onto the political scene at radically different political moments in the history of the United States. Nonetheless the economic, social, and political plight of many African Americans remains just as dire now as it was then. ${ }^{8}$ Washington and Obama both had to deal with issues of the problematic condition of black Americans. Obama notes correctly that the economic situation in the United States has been bad for all Americans. While it is true that Americans across the racial divide have been hit hard by the economic turndown, the African-American Community has been one of the hardest hit. The problems facing the African-American community have their roots in the racist history of the United States, and in the recurrent failure of the United States to address these problems connected with this history. Indeed this may be the most important difference between Obama and Washington. Washington understood the failure of the United States to fully incorporate African Americans into the social, economic, and political life of the country. ${ }^{9}$ Obama seems to think that the country has or is moving much closer too making the full inclusion of African Americans a social reality. This is the point at issue. While no one would claim that there has been no progress, there are questions as to whether the progress is only symbolic. ${ }^{10}$

7 While there was much excitement generated by his campaign, there is a suspicion that his policy-making after his election marks a setback for the full inclusion of African Americans into the social fabric of the United States. Obama, during his campaign and after, has consistently adhered to the view that making the lives of all Americans better will solve many of the problems of black Americans. For this reason, public policies should be colorblind. There is some truth to the claim that if all Americans do well, so will African Americans. But it seems also true that many of the problems-social, economic, and political - require "race conscious" policies. These are policies that are directed to the problems that plague the African-American community given the racist history and current instances of racism in the United States. I will cite some particular problems later in the paper.

In the United States, racism has impacted on the manner in which social goods have been distributed. For decades there were race conscious policies that favored whites over blacks. For years, persons of color were the victims of unjust social goods distribution policies. Policies such as Affirmative Action and "busing" were meant to address the maldistribution of social goods in the economic and educational spheres of life and the ways in which these inequities affected the lives of many African Americans. A race or at least a color conscious policy was needed to ensure that blacks were not again victimized by the maldistribution of social goods. In this regard, race becomes a factor in our understanding of the (re) distribution of social goods to correct for past injustices. These are called race or color conscious principles. These color and/or race conscious policies came under and still are attacked for being unfair and unjust. It was claimed that social justice required principles that were color-blind, that is, it was and remains wrong to use race or color as a principle for the distribution of social goods. Social justice requires race neutral policies for the distribution of social goods.

9 On the other hand, there are persons who believe that the racial climate in the United States has changed so drastically that the race of a person is insignificant in determining 
his or her success. Indeed persons, both black and white, think that race is no longer the dominant factor in the success or failure of persons of color. Their economic and social status is predicated solely on their own personal initiative. The United States is at that point in its history where qualifications and not race or color matter. If it is true that race is no longer a significant factor in the ability of a person of color to succeed, then there is no need for race conscious policies. Indeed some have maintained that Obama's election is proof that the United States has reached the point where color-blindness is the public attitude of most Americans. According to David Cochran, this color-blind paradigm relies on a particular set of normative categories in its understanding of race. These are its individualism, its focus on rights, its emphasis on fair procedures, its dedication to equality of opportunity, and its commitment to the principle of nondiscrimination. These categories lie at the heart of a powerful strand of liberal thought and practice over the past five decades, one that has become the dominant approach to issues of race. ${ }^{11}$

There is of course the strong version of color-blindness which entails that in our lives there should be no mentioning or consideration of race at all. Color-blindness in the context of this paper does not mean that we try to ignore race altogether. You can be proud of your race, claim your racial identity, you just cannot use race for public policy decisions. Color-blindness then becomes coupled with the distribution principle that goods be distributed according to merit. If the merit principle is applicable at this moment in American history, accordingly, we should embrace color-blind liberalism.

11 The move to what can be called "color-blind liberalism" should not be surprising to any one with knowledge of the social and political history of the United States. Given the history of racism it is not surprising that persons of all racial stripes would welcome colorblind principles. Indeed it has been the appeal of color-blindness that has prompted the enacting of laws to overturn many of the de jure segregation laws that were a part of this country's racist history.

That President Obama would draw on the color-blind paradigm also should not be surprising either. He is, as he often states, the president of America, not black America. Let us put away for the moment the cynicism that we might hold that for him to win the Presidency, he had to take a color-blind position. Rev. Wright reminded us that in the end Obama is a politician. ${ }^{12}$ Let us suppose for the sake of argument that Obama is deeply committed to a strong form of color-blind liberalism. That is, he thinks that at this moment in United States history we do not need to focus on race as a basis for public policy nor whom we elect for President. We need to and can look beyond race. We must be color-blind for the Country to move forward, together.

13 My aim in this paper will not be to discern what his stance on color-blindness is, but to show the importance of his stance as the focal point of current and future public policy. I will not herein be concerned with the division between the political right and left over what it means for a society to be color-blind, but will focus on Obama's projection of "color-blindness" as the way to shape race relations and public policy. I contend that totally color-blind public policies are the wrong approach to solving the problem of inclusion of black Americans into the social and political fabric of the United States. 


\section{Obama and Color-Blindness}

14 Obama's campaign and election rhetoric have consistently drawn on the color-blind principle. He gives no overt arguments against color-conscious policies; however, he just acts as if it is an obvious conclusion that public policy in the United States should be color-blind. In order to appreciate Obama's position on colorblindness we must put his position in both a historical and sociological context. Here, I want to draw on his speech of March 18th, 2008. This speech was given to distance himself from his former pastor Rev. Jeremiah Wright and to set the racial/race agenda for his campaign and policy considerations as President. What is at issue here is Obama's appeal to color-blindness as a focal point for his election. In this speech, among other things, Obama wants to express how the country has moved beyond race in very significant and important ways. While admitting that the country had a bad start regarding racial justice, the impetus for social justice was always present in the country's moral space. At one point in the speech, Obama sounds like a post-Garrison Frederick Douglass, ${ }^{13}$ when he states his opinion on slavery and the Constitution. Obama states that: "Of course, the answer to the slavery question was already embedded within our Constitution - a Constitution that had at is very core the ideal of equal citizenship under the law; a Constitution that promised its people liberty, and justice, and a union that could be and should be perfected over time." ${ }^{14}$ The United States, accordingly, was founded on principles that embodied respect for the individual and the task was to make the country live up to these principles. The goal has always been to celebrate individuals not races. Of course, the goal has not been reached. Obama states that his campaign is part of the historical push to make the United States a place where the individual can achieve to the best of his or her ability regardless of his or her race.

Obama: "This was one of the tasks we set forth at the beginning of this campaign to continue the long march of those who came before us, a march for a more just, more equal, more free, more caring and more prosperous America. I chose to run for the presidency at this moment in history because I believe deeply that we cannot solve the challenges of our time unless we solve them together - unless we perfect our union by understanding that we may have different stories, but we hold common hopes; that we may not look the same and we may not have come from the same place, but we all want to move in the same direction - towards a better future for our children and our grandchildren." 15

16 At this point, Obama begins some not so subtle shifts in his focus on what race means in the United States. The first move is from the African American experience in the United States to the emigrant experience. The story he tells of his mother's family is rooted in the emigrant story. Obama's life story is a story framed within the legacy of the emigrant story. Obama tells his now well-known life story, which I will not repeat. Obama notes, "It's a story that hasn't made me the most conventional candidate. But it is a story that has seared into my genetic makeup the idea that this nation is more than the sum of its parts - that out of many, we are truly one."

17 It is the story of the United States as the land of opportunity and the freedoms that it affords to all and our understanding of these values that unite Americans regardless of race, color, or creed. It is Obama's contention that it is these values that make us one great country. Still he understands that some people want to divide the country at a time people are looking for unity. 
Obama: "Throughout the first year of this campaign, against all predictions to the contrary, we saw how hungry the American people were for this message of unity. Despite the temptation to view my candidacy through a purely racial lens, we won commanding victories in states with some of the whitest populations in the country. In South Carolina, where the Confederate Flag still flies, we built a powerful coalition of African-Americans and white Americans." 16

It was clear that people were willing and could see beyond race. While some people were willing to be color-blind, others were not. The ugly specter of race began to intrude on his campaign. His own racial identity became a problem.

Obama: "At various stages in the campaign, some commentators have deemed me either 'too black' or 'not black enough.' We saw racial tensions bubble to the surface during the week before the South Carolina primary. The press has scoured every exit poll for the latest evidence of racial polarization, not just in terms of white and black, but black and brown as well." ${ }^{17}$

Still many people in the United States were able to see beyond race until his former pastor interjected race in a nasty way into the campaign. Wright called into question America's commitment to social justice for African Americans. Obama thinks that Wright took the discussion of race in a particularly divisive turn. Obama uses this moment to discuss the manner in which race and race conscious policies have impacted on both blacks and whites at opposite ends of the racial spectrum.

Obama: "On one end of the spectrum, we've heard the implication that my candidacy is somehow an exercise in affirmative action; that it's based solely on the desire of wide-eyed liberals to purchase racial reconciliation on the cheap. On the other end, we've heard my former pastor, Reverend Jeremiah Wright, use incendiary language to express views that have the potential not only to widen the racial divide, but views that denigrate both the greatness and the goodness of our nation; that rightly offend white and black alike." 18

Obama tells a story of the history of racism in the United States. He notes that Blacks have been subject to all sorts of racist policies and restrictions. It is this history that drives Rev. Wright and many older black Americans. He then draws the following conclusion regarding Rev. Wright:

Obama: "This is the reality in which Reverend Wright and other African-Americans of his generation grew up. They came of age in the late fifties and early sixties, a time when segregation was still the law of the land and opportunity was systematically constricted. What's remarkable is not how many failed in the face of discrimination, but rather how many men and women overcame the odds; how many were able to make a way out of no way for those like me who would come after them." 19

In essence, persons like Rev. Wright are still locked in a vision of the United States that reflects a terrible history, but in fact it is history. Wright and like-minded blacks have not moved beyond their memories of a race conscious United States. They are out of touch with the current social reality of the United States regarding race. They have failed to embrace the truly color-blind nature of the United States at this moment in history. On the other end of the spectrum, we find whites that are resentful about what they perceive to be the loss of their economic and social standing because of race conscious policies that seem to favor blacks. Obama notes that we must also understand that there is white resentment.

Obama: "In fact, a similar anger exists within segments of the white community. Most working- and middle-class white Americans don't feel that they have been particularly privileged by their race. Their experience is the immigrant experience 
- as far as they're concerned, no one's handed them anything, they've built it from scratch. They've worked hard all their lives, many times only to see their jobs shipped overseas or their pension dumped after a lifetime of labor. They are anxious about their futures, and feel their dreams slipping away; in an era of stagnant wages and global competition, opportunity comes to be seen as a zero sum game, in which your dreams come at my expense. So when they are told to bus their children to a school across town; when they hear that an African American is getting an advantage in landing a good job or a spot in a good college because of an injustice that they themselves never committed; when they're told that their fears about crime in urban neighborhoods are somehow prejudiced, resentment builds over time."20

He continues:

"Like the anger within the black community, these resentments aren't always expressed in polite company. But they have helped shape the political landscape for at least a generation. Anger over welfare and affirmative action helped forge the Reagan Coalition. Politicians routinely exploited fears of crime for their own electoral ends. Talk show hosts and conservative commentators built entire careers unmasking bogus claims of racism while dismissing legitimate discussions of racial injustice and inequality as mere political correctness or reverse racism" ${ }^{21}$.

23 It is the appeal to race that exacerbates these feelings of resentment. Accordingly, we must move beyond race. Holding on to bad memories and the media keeps the racial animosity potboiling. ${ }^{22}$ Public Policies that seem to favor one race over the other are another part of the problem. Obama thinks that we must acknowledge that both blacks and whites have bad feelings regarding race-based policies in the United States. What should blacks do?

Obama: "For the African American community, that path means embracing the burdens of our past without becoming victims of our past. It means continuing to insist on a full measure of justice in every aspect of American life. But it also means binding our particular grievances - for better health care, and better schools, and better jobs - to the larger aspirations of all Americans - the white woman struggling to break the glass ceiling, the white man whose been laid off, the immigrant trying to feed his family. And it means taking full responsibility for own lives - by demanding more from our fathers, and spending more time with our children, and reading to them, and teaching them that while they may face challenges and discrimination in their own lives, they must never succumb to despair or cynicism; they must always believe that they can write their own destiny." 23

Obama notes that Rev. Wright often preached what to many would seem like a conservative social position: "Ironically, this quintessentially American - and yes, conservative - notion of self-help found frequent expression in Reverend Wright's sermons. But what my former pastor too often failed to understand is that embarking on a program of self-help also requires a belief that society can change." Thus, it is not by means of race-based policies that the problems of blacks in America can be solved; policies must be color-blind coupled with individual responsibility. He then insists that blacks must believe that society has changed and can continue to change to improve the social and economic standing of blacks. In this regard, appeals to race-based public policies would be counter-productive. What must whites do?

Whites must understand black resentment! Whites must understand that there has been a history of racism that has impacted negatively on the economic and social standing of blacks. Blacks must understand White resentment. But in the end we must look beyond race. 
Obama: "If we disregard race we can look beyond historical impediments that have been used to hold or prevent persons of color making substantial social and economic gains in the United States. Drawing on color denies the mutual respect individuals should have. Not that we forget the history but the history cannot hold us down or separate. Whites must respect the history of racism and blacks must respect the feelings of whites that their understanding of the world has been shaken." 24

According to Obama, we must move beyond race. To do less will make the possibility of social progress nearly impossible. We should remember the history, but also remember that it is history. It is not the America in which we now find ourselves. Race has played a divisive role in the relationships between all persons in the United States. However, we are now at a different point in American history, a moment when character matters more than race. Accordingly, we must remember this if we are to perfect this union.

Obama: "In the end, then, what is called for is nothing more, and nothing less, than what all the world's great religions demand - that we do unto others as we would have them do unto us. Let us be our brother's keeper, Scripture tells us. Let us be our sister's keeper. Let us find that common stake we all have in one another, and let our politics reflect that spirit as well." ${ }^{25}$

Obama ends with a story of a white woman working for him because of his policies and the black man she was able to convince to work for Obama. In sum, his white supporters have been able to see beyond race and see the man (Obama) for his beliefs and principles. Many whites have become color-blind. If Blacks can come to this position America will move forward. The goal then is to create a society in which opportunities are not stalled because of those things for which a person is not responsible, particularly race or gender. ${ }^{26}$ It is however, up to the individuals to take responsibility for their own lives.

While, I must admit that these are noble goals and goals that we should work to achieve; we must admit that there is a big difference between citizens being color-blind in their choice of a presidential candidate and the president advocating color-blindness as the method of distribution of social goods. Race and racism still plays an important role in the lives of black Americans, indeed all Americans. We cannot and should not forget this important social fact.

\section{Color-Blindness and Obama}

According to Obama, race is no longer the most important factor preventing a person from being successful in the United States. What matters most is hard work, personal responsibility, and a belief and hope in America's ability to provide the best possible life for all of its citizens, regardless of race, gender, or ethnic background. What impression does this way of viewing the current racial climate in the United States create about race relations in the United States and those programs that might be direct to the problems of African Americans? Obama makes the not-so-subtle shift from color-blindness in voting to color-blindness in public policy. In doing so, he in the past three years through his policies and statements has

(1) Given the false impression that societal racism has lessened to a much greater degree than it has.

(2) Made it more difficult to propose social programs that are color conscious.

(3) Given the impression that color-blindness is absolute for all public policy.

(4) Taken away race-talk as a factor in public policy. 

standing of African Americans. Obama seems to be asking Blacks to give up insistence on race based public policies and view their future economic and social progress on programs solely meant to benefit all Americans. What is being asserted is that while it may be true that race and racism played an important part in the history of race relations, race and race conscious policies cannot be used to correct for the current conditions in which blacks find themselves. Hard work and personal responsibility are more important now. It is character that counts more than race. The questions are: Have we reached a stage in American history where character and qualifications trump the color of one's skin? Has racism diminished enough to not require race-based public policies? Obama appears to think that both of these questions can be answered in the affirmative.

Some will object and claim that Obama had to say and act like he does to get elected and reelected. In fact, Obama's plan is like William J. Wilson's hidden agenda in his book The Truly Disadvantaged. ${ }^{27}$ Wilson argues that we must hide programs for Blacks in program policies that are class based. We know if we try to use race based programs whites will not support them. In support of Obama, some will claim that he is just being pragmatic in that he could acknowledge that race is a problem, but it is not the major problem that needs his concern at the present moment. He also understands that to bring a discussion of race into the political mix will bog the country down. Here is the intellectual rub: Obama calls for Blacks to believe in a positive future in the United States and not make appeals to race or color conscious public policies. He is asking African Americans to put their faith in future Presidents to have their (Blacks) best interests as an important part of their public policy agenda. Should black Americans take this bet? I think not!

obama understands the pressure coming from both blacks and whites regarding race and his presidency. Blacks want him to show that he understands the plight of blacks and will do something positive as President to address their concerns. He is, indeed, black. Whites, on the other hand, want him to show no favoritism towards blacks. He is, indeed, black. Obama therefore must walk the line between supporting black interest and not offending white racial sensitivities. This may be why he couches his public policies as benefitting all Americans regardless of race. Still he has to show blacks that his programs have a positive impact on the black community, while these programs are geared to the larger American community.

President Obama also understands that some of his critics have strongly suggested that he has forsaken the black community. To address these charges, he appeared on BET TV to address black America and explain why his programs and policies were the best for all Americans including the majority of black Americans. In this interview, the President was asked about targeting programs to and for the African-American community. The President said that targeting one specific group is "not how America works." $\mathrm{He}$ continues that his policies are meant to help all Americans who are suffering at this time. Admitting that blacks are being hurt disproportionately, he thinks the majority of African Americans will be helped with his policies: "What has always made this country great is the belief that everybody has got a chance." "Regardless of race, regardless of creed." ${ }^{8}$ Public policies must be race and color-blind in order to help all Americans. In the end, Obama asks the African-American community to work hard, take responsibility for their lives and believe that all boats will rise with the improving economic tide. They must also believe that he is doing his part to make life better for all Americans. He is the President

European Journal of Pragmatism and American Philosophy, III-2 | 2011 
of all Americans; he is not just the president of black America. ${ }^{29} \mathrm{~A}$ few weeks later, President Obama released a 44-pages report on the positive impact his policies were having on the black community. ${ }^{30}$ There is some criticism that the report is very similar to the report on the poor given a few weeks earlier but this time with the emphasis on black Americans.

Has racism diminished enough to not require any race-based policies? Obama's speeches and public pronouncements seem to adhere to the belief that it has. In the end we must ask: Does Obama's move to color-blindness help or hurt the future of race relations in the United States? This is where the intellectual rubber meets the road. As I noted Obama adeptly draws on the liberal conception of the individual as the locus of social respect. We must look to those attributes to which the individual is responsible for to assess his or her accomplishments. People must take responsibility for their condition. The government should be working to make the lives of all citizens better regardless of race. Public policies must be colorblind. By drawing on color-blindness Obama does two things: he affirms the individual responsibility tradition that many whites and most blacks feel and he distances himself from issues of social justice that arise out of the civil rights era. This is not to deny the significant changes in the United States regarding race, it is, nonetheless, still unclear how deep these changes are in the hearts and minds of many white United States citizens. (Remember Obama only ask whites to understand that some Blacks are still resentful because of the history of racism.) Even if there is a deep and profound change in the attitudes of whites toward blacks, race conscious policies are needed to address some/many of the social problems confronting black Americans. (Blacks are asked to have faith and believe that the country will take their problems seriously.) These problems were caused by the use of race conscious policies and race conscious policies are needed to address the problems. If this is true then race-talk has to be a part of the nation's public policy discussion and race-conscious policies are needed to correct for past and current social injustices.

\section{Pragmatism and Race-Talk}

35 At this point, the reader might question what this has to do with pragmatism or what can pragmatism add to this discussion of public policy and race. ${ }^{31}$ In a pragmatic fashion, I needed to contextualize the above discussion of public policy and race-talk. I now want to draw on the work of philosopher Paul Taylor to show how a Deweyan pragmatic understanding of the role of race-talk can be used as a provocative critique of the Obama position on public policy and colorblindness. In what follows I will briefly articulate what I take to be important aspects of Taylor's analysis of a Deweyan pragmatism. I will then argue for the value of race-talk and race conscious public policies.

Taylor starts with the Deweyan insight that inquiry starts with a problem. The problem for the United States is how to complete the task of incorporating members of that population that have a history of chattel slavery into the full social and political fabric of the United States. This problem has historically been called the "Negro Problem." ${ }^{32}$ The problem has been in the United States: "What to do with the Negro?" The "Negro" problem for many persons in the United States was resolved with the passage of the Civil Rights Acts. Any problems blacks encounter currently cannot be attributed to societal racism, but to their own personal failings. Again race-talk or color conscious policies are unneeded to resolve the problems of African Americans. Can Dewey help us here? 

thinks he can give some social and political insight that while it may not solve the problem helps us to understand why race-talk is still needed to address the "Negro" problem. According to Taylor in the narrow, instrumental sense, pragmatism is the view that Dewy equated with this claim, "knowledge is instrumental to the enrichment of immediate experience through the control over action that it exercises." Taylor acknowledges that there is an evasive epistemology lurking behind this claim, but he is concerned with the manner in which this narrow pragmatic thesis expresses two familiar ideas. ${ }^{33}$ The first idea, call it practicalism, is that the condition of knowing involves being poised to intervene productively in the world's proceedings. The knowledge must be useful; it must help us make things better for us and our fellow humans:

describes knowledge as something that enriches experience. From this perspective, knowing how things stand involves - but is not equivalent to - being in a position to interact harmoniously and fruitfully with them. Knowledge is an instrument, and knowing is a practice and skill that helps us getting along better in the world. ${ }^{34}$

The second familiar idea behind the narrow pragmatic thesis, call it contextualism, is that inquiry, or the pursuit of knowledge, is value-laden and situational ${ }^{35}$ According to Taylor, "Dewey had in mind the now common point that we come to any inquiry, experiment, or question with aims, interests, desires, presumptions, and habits, and that these have some bearing on the answer that we get from the world or from our interlocutor." ${ }^{36} \mathrm{We}$ must examine and understand who is asking the question and why: "Thinking, we are too accustomed to saying, is relative; knowledge is pursued and produced somewhere, some when, and by someone, and these variable factors are not inconsequential. ${ }^{37}$ In this regard, who and why someone is asking the question is as important as the question. Persons of color in the United States who think that race and racism still impact on their lives are asking different questions about the use of race than the politician who is trying to present his or herself as a person of the people. Attending to the context of inquiry helps us decide which theoretical vocabulary is most appropriate to the situation, and to choose between theoretical vocabularies is also to choose between sets of entities and forces. ${ }^{38}$ The question of what kinds of policies are needed to improve the lot of African Americans will have differing answers depending on who is asking. There is the belief that there is some "real" perspective from which to answer the question. Dewey resisted this reductionist impulse. He insisted that there are different levels, different reals, valid for different purposes, and he made this contextualist pluralism an integral part of his pragmatism. ${ }^{39}$ It is often the case that there are certain ideological assumptions lurking beneath the epistemological surface of the answers proposed:

As individuals, we are more or less likely to see certain things in certain ways, sometimes because of the habits of cognition and perception into which we've been socialized, sometimes because of our deep and abiding interest in things being a certain way-a way, as it might be, that preserves our place in a power structure, or that undermines someone else's. Knowing this, we may wish to find some way of supplementing individual contributions to the process of inquiry, or of bringing individual interests and commitments to light (especially if, as it might be, these interests are opaque even to the agent in question). ${ }^{40}$

According to Taylor, "This is why Dewey insisted on the cooperative and self-corrective character of intelligent inquiry, and on the role of philosophy as, in his words, a criticism of the influential beliefs that underlie culture." ${ }^{41}$ Nonetheless, Taylor's approach to Deweyan pragmatism is not solely from the standpoint of an instrumentalist 
epistemology. It has a broader, metaphilosophical view. Like the narrower view, this metaphilosophy can be broken down into a few now familiar ideas. He refers to these as naturalism, experimentalism, and sodalism. ${ }^{42}$ By "naturalism" Taylor means to indicate a view with both metaphysical and methodological aspects. ${ }^{43}$ On the metaphysical side there are no intrinsically non-natural entities. A naturalist rejects the view of the super-natural and insists that the world is through and through a place of nomological regularities. ${ }^{44}$

Put another way, a way that highlights the methodological aspect of the view, the Deweyan naturalist holds that nothing is in principle inexplicable or inaccessible to the methods of science, even if, as it might be, we lack the cognitive or perceptual endowment that's necessary for finding the right explanations. For this Deweyan methodological naturalist, the basic pattern of explanation and inquiry used for science can usefully be generalized to other realms of human activity, including, as Dewey put it, the "social and humane subjects."

Taylor is quick to note: "This is not, as some have thought, an uncritical valorization of the scientific method and enterprise; it is, rather, an appeal to an ideal of science as a critical, cooperative, and self-corrective method for turning up resources to enrich human life." ${ }^{45}$ So a Deweyan methodological naturalism also demands a historicist and contextual sensibility. ${ }^{46}$

Science and reason can help us address the problems facing humans. This leads to the second element of Taylor's broad notion of pragmatism, experimentalism. He uses this label to indicate the view that, under the irremediable conditions of human finitude, all we can do is act, though more or less intelligently, and take our chances with the outcomes. Conduct is always dogged by the possibility of error, and though we try to minimize this possibility through the applications of intelligence, we can never shake it. That's what it is to be human. ${ }^{47}$ We must be willing to experiment with plans and policies. Dewey often criticized the philosophic fascination with necessity and certainty, with transcultural and suprahistorical standards, a fascination that he traced to the desire for metaphysical guarantees (which he in turn traced to antiquated notions of knowledge and experience and to something akin to existential dread). ${ }^{48}$ We must act boldly without a safety net. Pragmatic experimentalism rejects this quest for certainty and accepts instead the irreducible possibility of error, the radical contingency of things, and the need to act, to hypothesize and experiment, even in the absence of guarantees. ${ }^{49}$

The third element in Taylor's broad notion of pragmatism is sodalism. He notes that he adopted this term from the word "sodality": which in one of its senses means a fellowship, society, or association of any kind.$^{50} \mathrm{He}$ admits that the word is inelegant word, but it captures what he wants to convey about the role of associations as a basic feature of the human condition, and because all of the other words he might use to point to this perspective-communalism, socialism, holism-have connotations that are not relevant for his purposes. ${ }^{51}$

What I call pragmatic sodalism is concerned with the fact of human association in two respects. First of all, the broad sense of pragmatism takes philosophy to be an instrument for social improvement. Dewey's commitment to this view can be seen in his condemnation of philosophy that privileges abstract technical problems over the problems of everyday people. It can be seen in his depiction of philosophy as a kind of vision, as a practice of putting forward imaginative prophecies, which is to say 
hypotheses, of how the world might look if we comport ourselves differently. And it can be seen in his characterization of philosophy as a kind of criticism, in the definition I mentioned in the discussion of contextualism. ${ }^{52}$

In this regard, sodalism moves us away from the focus on individual and turns our attention to the communal associative nature of our lives. In this view, social problems may not become apparent, to say nothing of being solvable, until we ascend from the level of individual agency to the level of collective consequences, at which the patterns of social practice that "conjoint behavior" produces become more readily discernible. ${ }^{53}$

At this point Taylor thinks that he can give what would count as a pragmatic account of race. First, as a species of practicalism it would approach race theory as a practical endeavor, as an undertaking that helps us deal with, to paraphrase Dewey, the problems of people..$^{54}$ This means taking a hard look at the social realities facing people. The theories and devices that are needed to navigate one's life must take into account this reality. Taylor correctly notes: "Telling me that there are no races, even while populations mostly coterminous with the ones we used to think of as races can still be systematically distinguished by appeal to all sorts of social measures, is probably not an approach that helps me get around in a world shaped by white supremacy." ${ }^{55}$ His second point draws on the application of contextualism: pragmatic racialism would approach race-thinking, and accounts of race-thinking, as in conversation with their places and times, as the product of interaction among humans and between humans and their environments, and as situation-specific stories about social life. It would, in other words, concede that the concept of race depends on a particular cultural history for its very existence, and that specific applications or developments of the concept depend on particular local histories and conditions. ${ }^{56}$

Taylor admits to some this may seem to some to provide a reduction to any kind of racialism, ${ }^{57}$ but what it is doing is taking into account the social history that gave rise to the role of race in a given social context. Important for Taylor, in its third aspect as an instance of experimentalism, is to deny that races must appear on every ontological level in order to exist, and that "race" must refer to something transhistorical and (ontologically) objective in order to successfully refer. The experimentalist embrace of contingency also entails an insistence on the need to act, to be willing to intervene in ongoing processes and initiate change for the sake of improving existing conditions. ${ }^{58}$

Fourth, as a variety of naturalism, pragmatic racialism would reject out of hand the kind of super-naturalism that attends some varieties of racial essentialism. It would hold that we must account for the commonalities that unite members of a race, if there are any, without violating our usual patterns of observation and inference, and without suspending our commitment to the rest of what we count as knowledge..$^{59}$

We must see the development of the attitudes and practices of race and racism as Dewey sometimes said of other things, as a historical growth, as something that has come into being under specific but variable conditions. To do less, would be to reduce the complexity. ${ }^{60}$ Finally, as a sodalistic perspective, pragmatic racialism is anti-individualist. 61

52 A pragmatic racialism rejects the demand to reduce all collective action to the intentions of individuals and to assess all social phenomena from the standpoint of the individual. Instead, it accepts populations as in some respects, for some purposes, basic entities, which means locating individuals on the broader social terrain, and identifying individual 
perspectives as necessarily partial windows onto the relevant terrain. ${ }^{62}$ Taylor gives an example from Dubois.

I might decide that I don't want to be black, but, to use Dubois's famous "test" from Dusk of Dawn, if I am on a train in the state of Georgia in 1940, looking the way I do, I'd have to ride in the Jim Crow car, with all the black people. I'm not in a good position to interact with the world, to resist it even, unless I recognize what's likely to happen to me; and racial categories are an efficient and effective way of summing up my prospects under the conditions of white supremacy-as well as a point of entry into existing lines of antiracist organizing. So my pragmatism encourages me to add that I'd have to ride Jim Crow with all the other black people-not because we give racism the last word about who we are, but because effectively responding to racism requires realistically assessing how things are, and because centuries of antiracist work have made racial categories available as resources for mobilizing against racist assaults. ${ }^{63}$

I want to draw from Taylor the following: The social condition in which black Americans find themselves is a real condition of their experience of racism in the United States. Race has played and plays an important role in the living of their lives. They cannot live their lives as if race does not impact on the quality of their existence as citizens in the United States. If the leaders of the country are sincere about improving their status they must seriously take into account the manner in which race impacts on the economic and social existence of African Americans. A commitment to colorblindness in a society that is not colorblind seems to make little sense. If race still plays an important role in a group's social condition, race-talk must be a part of the conversation about public policy in the United States. Given the history and current status of racism, to do less would be to impede the future progress of African Americans and indeed all American citizens.

\section{Race-Talk, Color-Conscious Policies, and Social Needs}

It may be objected that I still have not shown that we need color-conscious policies, particularly race based policies. While I believe that color-conscious policies are both needed and permissible, my aim in this paper is much more modest. I only wanted to raise what I see as a problem with President Obama's seemingly unabashed support for color-blindness and not talking about race and racism as serious social problems in the distribution of social goods. As Taylor notes:

The vocabulary of race is a useful way of keeping track of a number of features of our conjoint social lives all at once-specifically, the features involved in the histories of systematically inequitable distributions, and in the continued patterning of social experiences and opportunity structures. It is a useful device because the concept has over the years come to connote registers of human experience-bodies, bloodlines, sex, and individual embedment-that might otherwise get obscured in social analyses, and because it can be used to abstract away from dimensions of experience-ethnicity, culture, and national origin-that receive adequate explanation in accounts that nevertheless fail to shed much light on specifically racial phenomena (involving the connections between bodies, bloodlines, and social location). ${ }^{64}$

If it is the case that African Americans are still denied housing, jobs, and other opportunities because of race, we do not live in a colorblind or post-racial America. This means, currently, race talk, race thinking, and race or color conscious public policies have work to do. It is clear that race and race consciousness still impacts on the lives of 
all Americans. The concern this raises for those of us who are concerned with issues of social justice is that President Obama, by claiming that his race neutral public policies will resolve the problems of the historic unjust race based distribution of social goods, takes race talk off the social agenda. By his actions and words, he is expressing the view that race-talk is unnecessary for social progress. This leads to the conclusion that whites will not support nor endorse race-based public policies that are meant to correct or ameliorate the social conditions of black folks. They (Whites) can rightly claim that the black President did not think the country needed race-based public policies.

However, if race-conscious policies are needed to address some of the problems that face the black community, President Obama should forthrightly say that this is the case. $\mathrm{He}$ can/will do this only if he takes the problem of racism in the United States seriously. President Obama knows that some of the problems that black Americans face are the result of current racist practices. He is also correct that these issues can or should be addressed by more strident equal enforcement of laws and programs that support the betterment of all Americans. There are, however, some problems that will require raceconscious policies. If it is the goal of the government to ensure that blacks get these social goods, race conscious policies will be needed.

Consider that at the present time we need black doctors to serve the larger black community, which is underserved. While programs like the National Health Service Corps attempts to get doctors to underserved areas, it has not provided enough physicians for these areas. Another problem with the NHS program is the lack of long-term commitment to these areas by the practicing physicians. In the case of underserved urban areas, doctors with a commitment to serve that population are needed. At this moment in our country's history, this means doctors with roots in those communities and who are committed to working with that population are needed and must be recruited. One way, perhaps, not the only way is to recruit persons from these areas to medical school. But such a policy would be race conscious. It may be possible that given time, enough black doctors would graduate from medical school to meet the need, or the government would make reimbursements sufficiently high enough to entice white doctors to work in these areas, or medical schools will train doctors with the necessary cultural sensitivity to want to work in those areas. There is also one more possibility: that the level of income will rise such that there are no longer any such communities. All of these are clearly longterm approaches. What should we do in the short-term?

If the United States Government wants to ensure that its black citizens will receive adequate health care in the near future, it will have to support policies that are raceconscious, in that they mark out race or ethnicity as a criterion for admission to medical school. This I think is a reasonable use of color-conscious race policies. One can only be surprised at this suggestion if he or she takes an ahistorical and decontextualized view of race and health care in the United States..$^{65}$ This is what a pragmatic understanding of race asks us to do, to take the social and historical context of racism into consideration.

If I am right here, then there are a number of social goods that can only be distributed at this time to the black community using race conscious policies. Legal, educational, and health concerns are among the pressing social needs of the black community. Let me state that I realize that African Americans are not the only group with such pressing problems, nor am I picking on President Obama because he is black; I think the same issues face any President black or white. 


\section{Conclusion}

61 Let me conclude by noting that I think that the election of a non-white male as President of the United States is significant and historic in nature. However, we must constantly be diligent in assessing President Obama's symbolic behavior regarding color-blindness and public policy. His seeming reliance on color-blindness is problematic for the advancement of racial and social justice for African Americans and the country as a whole. Listening to the political pundits talk about the importance of the Obama campaign and election made me realize the urgency of keeping his policy considerations under constant scrutiny. People have been too quick to move to a post-racial mode when it is not justified. Truly, we are not at that space or place in United States history where race no longer matters.

In this regard, we need to keep assessing Obama's public policies and, in particular, his guiding principles regarding the use of race. We need to do this because it forces us to constantly re-think the social and political status of those persons who have been consistently overlooked in the move to a more perfect union. There may come a time when colorblindness is the call of the hour, but we are not at that place or space now. To this end, a pragmatic understanding of race helps us to see why we still need both racetalk and race conscious policies. While the current economic downturn cannot be solely blamed on Obama, how the country deals with the issue of race and racism when the economy bounces back is to some degree in his control. We need to keep race-talk on the public policy agenda.

Obama, it could be claimed, is not against all color or race based public policies. Even if this is true, we have to be concerned with the symbolism of his actions. In his press conferences, he again and again pushes against connecting race as a factor in his presidency or his public policies. I want to raise two other concerns about his approach. First, by claiming that race need not be a factor in one's ability to succeed, President Obama gives the impression that it is the social behavior of blacks rather than the racism in society that prevents Blacks from advancing. This position takes the moral responsibility off whites and the government for past and current racist policies. Second, and closely connected to the first, the social responsibility approach reinforces the racist attitudes many whites have about blacks as lazy and not wanting to do what is necessary to make it in the United States. This reading of black behavior gives the impression that blacks are not worthy of being supported against racism beyond what has been done. Whites, as Obama noted, are resentful of blacks getting some advantage they (blacks) do not deserve. Is Obama fueling White animosity? Philosophers such as James Sterba and Elizabeth Anderson have published arguments that they think if given serious consideration by whites will reduce white animosity, if not to race-conscious policies, at least to some forms of Affirmative Action. ${ }^{66}$ One can only hope that they are correct in their assessments of white resentment towards blacks. ${ }^{67}$ Let me note that I am not claiming that societal racism relieves some blacks of any blame for their behavior, but only that the behavior of blacks is shaped in part by the racist social structure in which we are all forced to live.

As for our thinking about President Obama and colorblindness, it is important to note that his behavior regarding issues of race will set the tone for how many Americans understand the use of race in public policy, now and for years to come. Given his behavior and rhetoric over the past three years, race talk and color conscious policies will be 
forever off the political agenda. We must remember that the President's behavior is very symbolic. People are very symbol minded so we have to pay attention to symbols. Regardless of how significant President Obama's election was/is, we must call into question those behaviors that we think will do more harm than good. As Dubois said at the end of chapter 3 of Souls: "We have no right to sit silently by while the inevitable seeds are sown for a harvest of disaster to our children, black and white." ${ }^{68}$

\section{BIBLIOGRAPHY}

ANDERSON Elizabeth, (2010), The Imperative of Integration, Princeton, Princeton University Press.

BELL Derrick, (1992), “Racial Realism,” Connecticut Law Review, 24 (2), 363-79.

“Bill Moyers Interviews Rev. Jeremiah Wright," in These Times, accessed December 06, 2011. [ inthesetimes.com/article/3635/].

“Booker T. Washington's Atlanta Exposition Speech - Exhibitions - myLOC.gov (Library of Congress)." MyLOC.gov (Library of Congress). Accessed December 06, 2011. [myloc.gov/ Exhibitions/naacp/prelude/ExhibitObjects/BookerTWashingtonSpeech.aspx].

BoxILL Bernard R., (1984), Blacks and Social Justice, Totowa, Rowman \& Allanheld.

CARROLL Rebecca \& Booker T. WASHINGTON, (2006), Uncle Tom or New Negro: African Americans Reflect on Booker T. Washington and Up from Slavery 100 Years Later, New York, Harlem Moon.

совв William Jelani, (2010), The Substance of Hope: Barack Obama and the Paradox of Progress, New York, Walker.

COCHRAN David Carroll, (1999), The Color of Freedom: Race and Contemporary American Liberalism, Albany, State University of New York Press.

costello-nickitas Donna M., MIDdAugh Donna J., \& Nancy ARIES, (2011), Policy and Politics for Nurses and Other Health Professions: Advocacy and Action, Sudbury, Jones and Bartlett Publishers.

DoUGLASS Frederick, (2011), "Frederick Douglass on the Fourth of July, 1852," Metro DC Committee of Correspondence. Accessed November 13, 2011. [redandgreen.org/speech.htm].

DUBois W. E. B., (2011), “The Souls of Black Folk,” University of Virginia Library. Accessed November 13, 2011. [etext.virginia.edu/toc/modeng/public/DubSoul.html].

“Employment Situation Summary," U.S. Bureau of Labor Statistics. Accessed December 06, 2011. [bls.gov/news.release/empsit.nr0.htm].

HARVEY-WINGFIELD Adia, \& Joe R. FEAGIN, (2010), Yes We Can?: White Racial Framing and the 2008 Presidential Campaign, New York, Routledge.

LAWSON Bill E., (2004), "Booker T. Washington: A Pragmatist at Work," in Pragmatism and the Problem of Race, Bloomington, Indiana University Press, 125-41.

LAWSON Bill E., (2011), “Sterba on Affirmative Action, Or, It Never Was the Bus, It Was Us!," The Journal of Ethics, 15 (3), 281-90 (doi:10.1007/s10892-011-9104-4). 
LAWSON Bill E., \& Donald F. KоСH, (2004), Pragmatism and the Problem of Race, Bloomington, Indiana University Press.

MOSES Michele S., (2002), Embracing Race: Why We Need Race-conscious Education Policy, New York, Teachers College Press.

NEWMAN Judie, TRODD Zoe, LAWSON Bill E., \& Fionnghuala SWEENEY, (2011), "Roundtable: ‘The Horrible Gift of Freedom,' Marcus Wood," Journal of American Studies, 45 (1), 163-83.

OBAMA Barack (2011), “Barack Obama's Speech on Race in America - FULL - 2008-03-18 -

YouTube.” YouTube - Broadcast Yourself. Accessed December 06, 2011. [youtube.com/watch? $\left.\mathrm{v}=\mathrm{ffXOSEj} \_\mathrm{SQM}\right]$.

Occupy Together | Home. Accessed December 06, 2011. [occupytogether.org/].

“The President Discusses the Economic Crisis | Videos | BET". Celebrities, Music, News, Fashion, Entertainment, TV Shows and Video | BET. Accessed December 06, 2011. [bet.com/video/ newsbriefs/betnewsspecial/obama092311-s02.html].

"The President's Agenda and the African American Community," Scribd, Accessed December 06, 2011. [scribd.com/doc/72691786/The-President-s-Agenda-and-the-African-AmericanCommunity].

"Speech Before the Atlanta Cotton States and International Exposition by Booker T.

Washington." TeachingAmericanHistory.org - Free Seminars and Summer Institutes for Social Studies Teachers. Accessed November 10, 2011. [teachingamericanhistory.org/library/index.asp? document $=69$ ].

STERBA James P., (2009), Affirmative Action for the Future, Ithaca, Cornell University Press.

SUNDQUIST Eric J., (2009), King's Dream, New Haven, Yale University Press.

TAYLOR Paul C., (2004), "Pragmatism And Race," in Pragmatism and the Problem of Race.

Bloomington, Indiana University Press.

WILLIAMS David R., \& Toni D. RUCKER, (2000), "Understanding and Addressing Racial Disparities in Health Care," Health Care Financing Review, 21 (4), Summer, 75-90.

WILSON William J., (1990), The Truly Disadvantaged: the Inner City, the Underclass, and Public Policy, Chicago, University of Chicago Press.

WILSON William J., (2009), More than Just Race: Being Black and Poor in the Inner City, New York, Norton \& Company.

\section{NOTES}

1. W. E. B. Dubois, "The Souls of Black Folk," University of Virginia Library, "Of Mr. Booker T. Washington and Others," accessed November 13, 2011, [etext.virginia.edu/toc/modeng/public/ DubSoul.html]. Hereafter, "Souls."

2. Souls.

3. Lawson 2004.

4. Rebecca Carroll \& Booker T. Washington 2006.

5. See, for example, Sundquist 2009.

6. "Speech Before the Atlanta Cotton States and International Exposition by Booker T. Washington," TeachingAmericanHistory.org - Free Seminars and Summer Institutes for Social 
Studies Teachers, section goes here, accessed November 10, 2011, [teachingamericanhistory.org/ library/index.asp?document=69].

7. "Barack Obama Speech at DNC" - Barack Obama Speech at 2004 Democratic National Convention, Welcome to Chicago.About.com, section goes here, accessed November 10, 2011, [ chicago.about.com/od/chicagopeople/a/DNCSpeechobama.htm].

8. [bls.gov/news.release/empsit.nro.htm], see for black unemployment rate, October 2011.

9. Newman, Trodd, Lawson \& Sweeney 2011.

10. This raises some interesting questions about the concept of progress and race relations in the United States. For a discussion of the symbolic nature of the seemingly social progress in the United States, see Bell 1992.

11. Cochran (1999: 17).

12. [inthesetimes.com/article/3635/] accessed November 10, 2011.

13. Douglass 2011

14. Obama 2011. Hereafter "The Speech."

15. The Speech.

16. The Speech.

17. The Speech.

18. The Speech.

19. The Speech.

20. The Speech.

21. The Speech.

22. Harvey Wingfield \& Feagin 2010.

23. The Speech.

24. The Speech

25. The Speech.

26. Boxill 1984.

27. Wilson 1990

28. The President Discusses the Economic Crisis | Videos | BET, Celebrities, Music, News, Fashion, Entertainment, TV Shows and Video | BET, section goes here, accessed December 06, 2011, [ bet.com/video/newsbriefs/betnewsspecial/obama092311-s02.html].

29. Cobb 2010.

30. "The President's Agenda and the African American Community," Scribd, section goes here, accessed December 06, 2011, [scribd.com/doc/72691786/The-President-s-Agenda-and-theAfrican-American-Community].

31. Lawson \& Koch 2004.

32. See, for example, Dubois, Souls: "BETWEEN me and the other world there is ever an unasked question: unasked by some through feelings of delicacy; by others through the difficulty of rightly framing it. All, nevertheless, flutter round it. They approach me in a half-hesitant sort of way, eye me curiously or compassionately, and then, instead of saying directly, How does it feel to be a problem? they say, I know an excellent colored man in my town; or, I fought at Mechanicsville; or, Do not these Southern outrages make your blood boil? At these I smile, or am interested, or reduce the boiling to a simmer, as the occasion may require. To the real question, How does it feel to be a problem? I answer seldom a word."

33. Taylor (2004: 164).

34. Taylor (2004: 164).

35. Taylor (2004: 164).

36. Taylor (2004: 164).

37. Taylor (2004: 164).

38. Taylor (2004: 164).

39. Taylor (2004: 164).

European Journal of Pragmatism and American Philosophy, III-2 | 2011 
40. Taylor (2004: 165).

41. Taylor (2004: 165).

42. Taylor (2004: 165).

43. Taylor (2004: 165).

44. Taylor (2004: 165).

45. Taylor (2004: 165).

46. Taylor (2004: 165).

47. Taylor (2004: 166).

48. Taylor (2004: 166).

49. Taylor (2004: 166).

50. Taylor (2004: 166).

51. Taylor (2004: 166).

52. Taylor (2004: 166).

53. Taylor (2004: 167).

54. Taylor (2004: 167).

55. Taylor (2004: 167).

56. Taylor (2004: 167).

57. Taylor (2004: 167).

58. Taylor (2004: 167).

59. Taylor (2004: 168).

60. Taylor (2004: 168).

61. Taylor (2004: 168).

62. Taylor (2004: 168).

63. Taylor (2004: 168).

64. Taylor (2004: 168).

65. Williams \& Rucker (2000: 76).

66. Anderson 2010, and Sterba 2009.

67. Lawson 2011.

68. Souls.

\section{ABSTRACTS}

The election of Barack H. Obama as President of the United States was a significant event in the social and political history of the United States. His election as the first non-white male President has been seen as a sign of the changing racial attitudes of white Americans. Nonetheless, the specter of race and racism haunts his presidency. As the first African American president, he has to show the black community that he has their social, political, and economic interests on his public policy agenda. On the other hand, he cannot appear to be to overtly pro-black without bruising white racial sensibilities. In order to walk this fine line, President Obama has taken a colorblind approach to public policies. He claims that his color-blind public policies will help to uplift all citizens regardless of race, creed, or national origin. Important for this discussion is the claim that race need not be a factor in public policies. There are some doubts about this claim given the history of anti-black racism in the United States. It is argued, herein, that color or race conscious policies are needed to address some of the social and economic problems that besiege 
the black community. This article utilizes a pragmatic account of race to illustrate why colorblindness in public policies takes an ahistorical and decontextualized view of race and in the long term will hurt the social and economic standing of African Americans in the move to a more perfect union.

\section{AUTHOR}

\section{BILL E. LAWSON}

University of Memphis

belawson[at]memphis.edu 